\title{
Effect of Nitrogen and Water Management on Methane Emission of Boro Rice Cultivation in Bangladesh
}

\author{
Israt Zahan ${ }^{1}$, Shahadat Hossen ${ }^{1 *}$, Akhter Hossain Chowdhury ${ }^{2}$, Abdul Baten ${ }^{1}$ \\ ${ }^{1}$ Department of Environmental Science, Bangladesh Agricultural University, Mymensingh, Bangladesh \\ ${ }^{2}$ Department of Agricultural Chemistry, Bangladesh Agricultural University, Mymensingh, Bangladesh \\ Email: *mshossen@bau.edu.bd
}

How to cite this paper: Zahan, I., Hossen, S., Chowdhury, A.H. and Baten, A. (2018) Effect of Nitrogen and Water Management on Methane Emission of Boro Rice Cultivation in Bangladesh. Journal of Geoscience and Environment Protection, 6, 90-100. https://doi.org/10.4236/gep.2018.67007

Received: May 7, 2018

Accepted: July 24, 2018

Published: July 27, 2018

Copyright (c) 2018 by authors and Scientific Research Publishing Inc. This work is licensed under the Creative Commons Attribution International License (CC BY 4.0).

http://creativecommons.org/licenses/by/4.0/

\begin{abstract}
Water and nitrogen are two key elements required for successful rice cultivation. We examined the responses of nitrogen and water management on methane emission of Boro rice in the field laboratory of Bangladesh Agricultural University research farm, Mymensingh. Three treatments were studied in the field experiment viz, T1: Control plot (no nitrogen fertilizer), T2: Urea super granule $(78 \mathrm{~kg} \mathrm{~N} / \mathrm{ha})$, T3: Prilled urea (104 kg N/ha) with three replications under two water management of Continuous Standing Water (CSW) and Alternate Wetting and Drying (AWD). Air samples were collected by the closed-chamber method and methane gas was determined by gas chromatography. The highest $\mathrm{CH}_{4}$ emission was found from CSW plots and the lowest from AWD plots. Under CSW condition, the effects of urea treatments on $\mathrm{CH}_{4}$ emission were not significant. In case of urea treatments, the highest $\mathrm{CH}_{4}$ emission was observed from treatment T3 under CSW condition and T2 under AWD condition and the lowest emission was from the control treatment. The overall results suggest that prilled urea and urea super granule should be applied under AWD and CSW condition, respectively to keep less $\mathrm{CH}_{4}$ emission from irrigated rice agriculture.
\end{abstract}

\section{Keywords}

Methane, Urea Super Granule, Prilled Urea, Alternate Wetting and Drying, Boro Rice

\section{Introduction}

Rice is the staple food for the people of Bangladesh. Total rice production in Bangladesh was 10.32 million tons in the year 1975-76 when the country's pop- 
ulation was only 79.90 millions and cultivated rice area was 10.32 million hectare. However, the country had produced 18.93 million tons Boro rice in the year of 2014-15 which contributed more than $50 \%$ to the total rice production [1].

Increasing concentration of greenhouse gases (GHGs) is responsible for global warming and climate change. $\mathrm{CH}_{4}$ is considered as the second important greenhouse gas after $\mathrm{CO}_{2}$ which has 25 times more global warming potential (GWP) than carbon dioxide contributing to $16 \%$ of the global warming. The concentration of $\mathrm{CH}_{4}$ in the atmosphere has been increasing in the last $200 \mathrm{yr}$ and has reached $1.77 \mathrm{ppm}$ by volume in 2005, which is over double than that of its pre-industrial value [2]. There are two major sources of methane emissions: one is natural source and another is anthropogenic source. More than $50 \%$ of the global annual $\mathrm{CH}_{4}$ emission is of anthropogenic origin [3]. It is reported that irrigated rice accounts for more than $75 \%$ of global rice production and these rice fields are one of the major sources of $\mathrm{CH}_{4}$ gas [4]. Since irrigated rice remains continuously flooded most of the time during rice growing season, this creates the ideal condition for $\mathrm{CH}_{4}$ emissions. It is reported that $\mathrm{CH}_{4}$ emission from rice fields varies within the range of 39 and $112 \mathrm{Tg} \mathrm{CH}_{4}$ year $^{-1}$ which is equivalent to $6 \%$ to $18 \%$ of total global $\mathrm{CH}_{4}$ flux [5]. Paddy rice methane generates roughly 500 million tons of emissions of carbon dioxide equivalent $\left(\mathrm{CO}_{2} \mathrm{e}\right)$ per year. For most rice growing countries in Southeast Asia, rice contributes around 50 percent of agricultural emissions and from 2.5 percent to more than 20 percent of total emissions.

A statistical analysis of the $\mathrm{CH}_{4}$ emission fluxes from rice fields in Asia showed that the average $\mathrm{CH}_{4}$ flux during the growing season is significantly affected by water management, organic matter application, soil organic carbon content, soil $\mathrm{pH}$, and climate [6]. It is also influenced by soil type, weather, tillage management, residues, fertilizers, and rice cultivar. Therefore, manipulation of this factor can help to reduce $\mathrm{CH}_{4}$ emissions. Thus, several studies were conducted to mitigate $\mathrm{CH}_{4}$ emissions in rice fields through soil and water management [7]. In order to reduce greenhouse gas emissions from rice cultivation, $\mathrm{Al}$ ternate Wetting and Drying (AWD), a water saving method developed by IRRI in 1997, helps to reduce water requirement about $30 \%$ without any yield reduction. It is reported that intermittently flooded regimes emitted distinctly less $\mathrm{CH}_{4}$ than the continuously flooded system [8]. Since methane emission is higher during flowering to maturity stages, drying of field during later stages (i.e., close to the flowering stage) could result in a greater reduction in $\mathrm{CH}_{4}$ emissions [9]. Methane emission can also be affected by fertilizer application. Generally, organic fertilizer increases emissions compared with chemical fertilizer. Application of urea at low rate generally increases methane emissions [10] [11]. However, the effects of its application methods such as broadcast or deep placement on methane emissions are very limited. Urea Deep Placement (UDP) or urea super granule is a fertilizer management technology which helps to increase crop yield $(15 \%-20 \%)$ and reduce nitrogen loss by up to $30 \%$ mainly due to reduced vola- 
tilization loss compared with broadcast urea application [12]. It also significantly reduced $\mathrm{N}_{2} \mathrm{O}$ emissions during rice growing period compared with broadcast urea [13]. Moreover, there are few studies in Bangladesh about methane emission from rice cultivation. Therefore, this study was conducted to compare the $\mathrm{CH}_{4}$ emissions from UDP vs. urea broadcast in two water management conditions.

\section{Materials and Methods}

\subsection{Experimental Site and Weather Conditions}

The field experiment was conducted from December 2013 until April 2014, during Boro rice growing season, at the experimental field of Soil Science Department of Bangladesh Agricultural University, Mymensingh $\left(24^{\circ} 75^{\prime} \mathrm{N}\right.$, $90^{\circ} 50^{\prime} \mathrm{E}, 18 \mathrm{~m} \mathrm{MSL}$ ). The location experiences a tropical monsoon-type climate, with a hot and rainy summer, and dry winter. Annual mean air temperature was $25.4^{\circ} \mathrm{C}$, and annual rainfall was $2055 \mathrm{~mm}$. The usual cropping pattern is rice-fallow-rice, where dry-season rice, locally called "Boro" rice, which is cultivated from February to May and wet-season rice, locally called "Aman" rice, which is cultivated from August to December. The field is mostly irrigated during the Boro rice period, while it is rain-fed during the Aman rice period. The soil is Non-Calcareous Dark Grey Floodplain Soil under the Old Brahmaputra Floodplain Agro Ecological Zone (AEZ 9) of Sonatala soil series. The experimental soil was composed of: $0.18 \%$ total nitrogen, $3.3 \%$ organic matter, $\mathrm{pH} 6.25$ $\left(1: 2.5 \mathrm{H}_{2} \mathrm{O}\right)$ and EC $0.2 \mathrm{dS} \cdot \mathrm{m}^{-1}$, available $\mathrm{P}$ was $12.76 \mathrm{mg} \cdot \mathrm{kg}^{-1}$ and exchangeable $\mathrm{K}$ (me/100g soil) was 0.13 [14].

\subsection{Experimental Design and Treatments}

Three treatments of urea fertilizer application $\mathrm{T}_{1}$ : Control plot (No nitrogen fertilizer); $\mathrm{T}_{2}$ : Urea Super Granule (USG) (one $2.7 \mathrm{~g}$, $78 \mathrm{~kg} \mathrm{~N} / \mathrm{ha}$ ); and $\mathrm{T}_{3}$ : Prilled Urea (PU) (104 kg N/ha) under two water management system viz. continuous standing water (CSW) and alternate wetting and drying (AWD) experiments. Treatments were arranged in a randomized complete block design (RCBD). The area of each plot size was $20.16 \mathrm{~m}^{2}(5.6 \mathrm{~m} \times 3.6 \mathrm{~m})$.

\subsection{Crop Field Management}

All the fertilizers except nitrogen such as phosphorus $(\mathrm{P})$, potassium $(\mathrm{K})$, sulfur $(\mathrm{S})$ and zinc $(\mathrm{Zn})$ were applied in all the plots at the time of final land preparation as a basal application. Fertilizer $\mathrm{P}$ was applied as single super phosphate at the rate of $25 \mathrm{~kg} \mathrm{P} / \mathrm{ha}$. $\mathrm{K}$ was applied as muriate of potash at the rate of $85 \mathrm{~kg}$ $\mathrm{K} / \mathrm{ha}$. Sulfur and zinc were applied at the rate of 20 and $3 \mathrm{~kg} \cdot \mathrm{ha}^{-1}$. In control plot no nitrogen was applied. Nitrogen $(\mathrm{N})$ was applied by two methods based on treatments, one as urea broadcast and another as deep placement of urea (also called super granule). Broadcast urea was applied as three equal split while bri- 
quette were applied as a single application 15 days after transplanting (DAT). Super granules were applied at $8-10 \mathrm{~cm}$ depth between four hills of rice. All plots were irrigated after transplanting. CSW plots were irrigated regularly but the AWD plots were irrigated based on AWD principle followed by the project. Irrigation of AWD plots were based on reading of AWD pipes inserted into each plots. When water goes below $15 \mathrm{~cm}$ from the surface, only then plots were irrigated. Irrigation was stopped before 2 weeks of harvest.

\subsection{Gas Sampling}

Twelve automated plexiglass chambers designed by the International Fertilizer Development Center were installed in experimental site. Out of 12 chambers, nine chambers were installed under the CSW plots (three treatments, three replications) and three chambers were installed under AWD non-replicated plots. Details of gas chamber are available in [13] [15]. Six air samples were taken at eight-minute intervals $(0,8,16,24,32$, and $40 \mathrm{~min})$ for $40 \mathrm{~min}$ at every three-hour sampling sequence. The zero-minute sample taken with open chamber represented the ambient air. Gas sampling was done manually every week from 09:00 to 12:00 from the exhaust of $\mathrm{N}_{2} \mathrm{O}$ analyzer (Model T320U). Since $\mathrm{N}_{2} \mathrm{O}$ analyzer analyzed gas sample by non-destructive measure, the gas exhausted from the analyzer should be the same concentration as the gas sampled from the chamber. Only two samples were collected from each chamber, one before closing the chamber $(0 \mathrm{~min})$ and another after $40 \mathrm{~min}$ just before opening of the chamber. Four chambers were sampled in an hour. Twelve chambers were sampled from 09:00 am. to 12:00 pm. Gas samples were collected weekly from maximum tillering to maturity stages. Gas samples were collected using in $50 \mathrm{ml}$ plastic syringes. The collected samples were stored in an evacuated glass vials until its laboratory analysis.

\subsection{Calculation of Methane Flux}

The samples were analyzed to determine the concentration of $\mathrm{CH}_{4}$ gas by gas chromatograph equipped with a Flame Ionization Detector (FID) (Shimadzu-2014, Japan). The analysis column used a stainless steel column packed with HAYSEP Q 80/100. The temperatures of column, injector and detector were adjusted at $120^{\circ} \mathrm{C}, 200^{\circ} \mathrm{C}$, and $220^{\circ} \mathrm{C}$ respectively. The column flow was $25 \mathrm{ml} / \mathrm{min}$.

Flux (F) $=\mathrm{mg} \mathrm{CH}_{4}$ emission rates were calculated from the slope of the linear regression curve of gas concentration against chamber closure time $\left(\mathrm{ppm} \cdot \mathrm{min}^{-1}\right)$. The emission rates in $\mathrm{ppm} \cdot \mathrm{min}^{-1}$ were converted to $\mathrm{mg} \cdot \mathrm{m}^{-2} \cdot \mathrm{d}^{-1}$ as follows [9]:

$$
\mathrm{CH}_{4} \text { emission }\left(\mathrm{mg} \cdot \mathrm{m}^{-2} \cdot \mathrm{d}^{-1}\right)=\frac{\operatorname{Slope}\left(\mathrm{ppm} \cdot \mathrm{min}^{-1}\right) \times 56.7 \times 16 \times 60 \times 24}{22.4 \times \frac{273+t}{273} \times 0.149 \times 1000}
$$

where 56.7 is the volume of the gas chamber in liters (L), 16 is the molecular weight of $\mathrm{CH}_{4}, 60$ and 24 are the time correction factors (to convert into day), 
22.4 is the volume of 1 mole of gas in $\mathrm{L}$ at standard temperature and pressure, 273 is the standard temperature in ${ }^{\circ} \mathrm{K}, \mathrm{T}$ is the temperature inside the chamber in ${ }^{\circ} \mathrm{C}, 0.146$ is the area occupied by the chamber in $\mathrm{m}^{2}$, and 1000 is $\mu \mathrm{g} \cdot \mathrm{mg}^{-1}$.

Estimates of cumulative $\mathrm{CH}_{4}$ emissions were calculated from the sum of daily emission rates. Daily emission rates in between weekly measurements were estimated by linear interpolation of two consecutive weekly measurements.

\section{Results and Discussion}

\subsection{Water Depth in Experimental Plots}

Average water depths of CSW plots and AWD plots are shown in Table 1. Average water depth of plots under CSW condition were ranged from $1.8 \mathrm{~cm}$ to 7.1 $\mathrm{cm}$. Plots were dried only two weeks before harvesting of rice. Water depth was almost similar in all treatments during each sampling date. Under AWD condition, average water depths ranged from $-9.5 \mathrm{~cm}$ to $6.9 \mathrm{~cm}$. The water depths were similar to CSW plots when all the plots were irrigated, but when the AWD plots became dried the water depths were less than the CSW plots, and the variation of water depth also observed in different treatment. Negative water depth indicates the depth of water below soil surface. Generally plots were irrigated when water goes below $15 \mathrm{~cm}$ from soil surface. Van der Hoek et al. [16] found that alternate wet/dry irrigation save $29 \%$ of water of over conventional irrigation in Japan without significant yield reductions (7.2 vs $7.8 \mathrm{t} / \mathrm{ha}$ ).

\subsection{Dynamics of Methane Emissions during Boro Rice Cultivation}

Methane emission rates from paddy field soil are shown in Figure 1. Methane emissions were recorded at 38,44, 51, 58, 65, 72, 79, 86, 93, and 100 DAT from both CSW and AWD plots. Methane emissions increased from panicle initiation stage (60 DAT) to flowering stage (85 DAT) in all treatments under both CSW and AWD plots. Climatic condition is also changed during this time which is also responsible for higher $\mathrm{CH}_{4}$ emission. Emission rates decreased after flowering stage (90 DAT) up to maturity stage.

The highest emission rates under CSW condition, were 24.1 (86 DAT), 24.4 (86 DAT) and 30.5 (86 DAT) $\mathrm{mg} \cdot \mathrm{m}^{-2} \cdot \mathrm{d}^{-1}$, respectively for control, USG and PU treatments respectively. The lowest emission rates were 2.69 (100 DAT), 2.07 (38 DAT), and $4.56(100 \mathrm{DAT}) \mathrm{mg} \cdot \mathrm{m}^{-2} \cdot \mathrm{d}^{-1}$ respectively for control, USG and PU treatments respectively. Similarly the highest emission rates under AWD condition were 13.8 (72 DAT), 28.7 (86 DAT) and $21.5(86 \mathrm{DAT}) \mathrm{mg} \cdot \mathrm{m}^{-2} \cdot \mathrm{d}^{-1}$, respectively for control, USG and PU treatments. The lowest emission rates were -3.74 (100 DAT), -1.86 (38 DAT), and $-2.88(100 \mathrm{DAT}) \mathrm{mg} \cdot \mathrm{m}^{-2} \cdot \mathrm{d}^{-1}$, respectively for control, USG and PU treatments. Pattern and trends of emission rates were similar among the treatments. Magnitudes of emission rates were also similar among treatments under CSW but they were different under AWD condition where USG showed lower magnitude at early stage but higher in later stage compare with others. This result is similar with previous studies where they also 
Table 1. Average water depths of plots under CSW and AWD condition.

\begin{tabular}{|c|c|c|c|c|c|c|}
\hline \multirow{3}{*}{ DAT } & \multicolumn{3}{|c|}{ Continuous Standing Water (CSW) } & \multicolumn{3}{|c|}{ Alternate Wetting and Drying (AWD) } \\
\hline & \multicolumn{3}{|c|}{ Depth $(\mathrm{cm})$} & \multicolumn{3}{|c|}{ Depth $(\mathrm{cm})$} \\
\hline & Control & USG & PU & Control & USG & PU \\
\hline 38 & 7.0 & 6.4 & 4.9 & 5.7 & 6.9 & 5.1 \\
\hline 44 & 4.4 & 3.8 & 4.0 & 4.1 & 3.3 & 3.8 \\
\hline 51 & 6.3 & 5.5 & 5.3 & -4.7 & -3.3 & -6.9 \\
\hline 58 & 4.1 & 4.1 & 3.6 & 3.9 & 4.7 & 2.8 \\
\hline 65 & 4.8 & 4.2 & 4.4 & 2.9 & 0.5 & 0.7 \\
\hline 72 & 4.3 & 3.1 & 4.4 & 6 & 4.4 & 1.9 \\
\hline 79 & 1.9 & 3.1 & 1.8 & 3.3 & 4.6 & 3.4 \\
\hline 86 & 6.7 & 7.1 & 6.7 & 6.4 & 5.8 & 6.9 \\
\hline 93 & 3.3 & 3.0 & 2.6 & -3.5 & -1.8 & -5.9 \\
\hline 100 & 2.4 & 1.8 & 1.8 & -5.1 & -3.2 & -9.5 \\
\hline
\end{tabular}
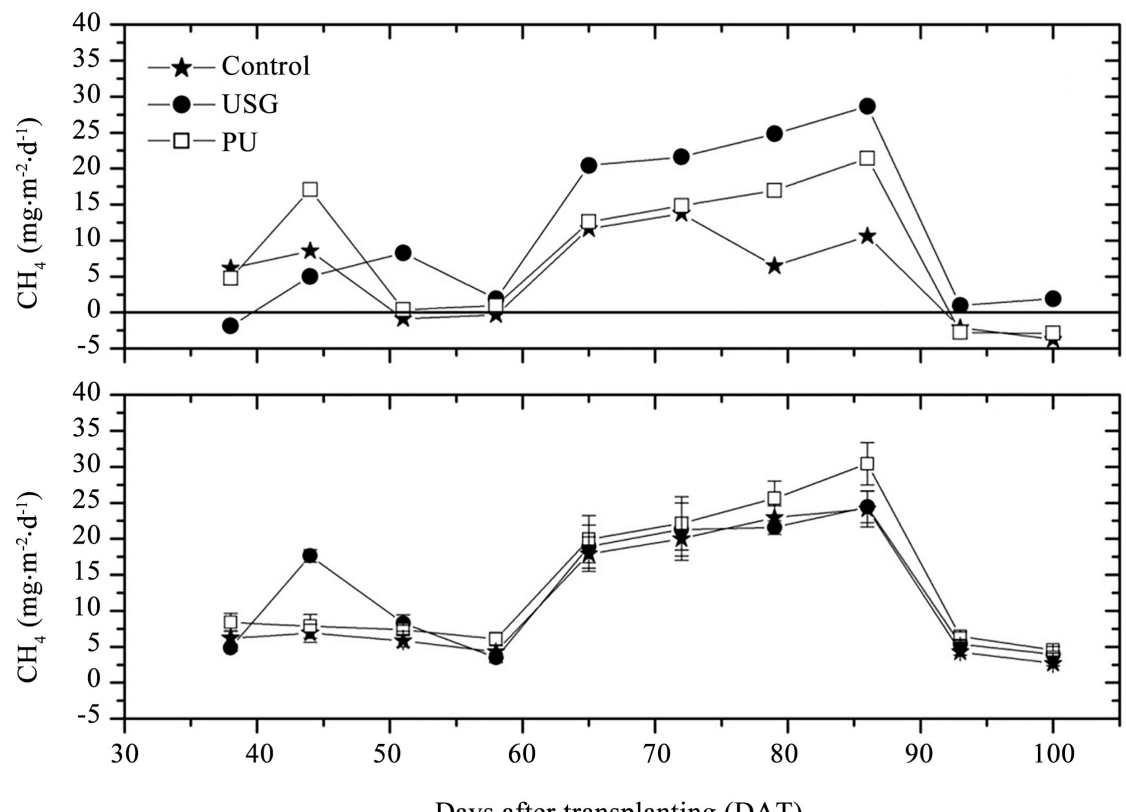

Figure 1. Dynamics of methane emissions in different fertilizer and water treatments. Error bar indicate standard error. (a) AWD; (b) CSW.

observed increasing methane emissions with rice growth and higher during reproductive stage and decreased towards maturity stage [9]. The highest $\mathrm{CH}_{4}$ emission $\left(61.49 \mathrm{mg} \cdot \mathrm{m}^{-2} \cdot \mathrm{h}^{-1}\right)$ was observed at the flowering stage of treatment of $50 \mathrm{t} \cdot \mathrm{ha}^{-1}$ organic treatment the lowest $\mathrm{CH}_{4}$ emission $\left(18.93 \mathrm{mg} \cdot \mathrm{m}^{-2} \cdot \mathrm{h}^{-1}\right)$ was observed at the transplanting stage of control plot in T-aman rice field of Bangladesh [17]. The $\mathrm{CH}_{4}$ that is released to the atmosphere escapes through three pathways: diffusion of dissolved $\mathrm{CH}_{4}$ gas, loss through ebullition (gas bubbles), 
and mainly (80\% - 98\%) by plant transport through the aerenchyma [18] [19]. Emission rate measured here was relatively lower compared with the previous studies. This is because gas sampling in this study was done without rice plants. It is well known that rice plants emit most of the methane from soil to atmosphere. Previous studies also showed that, up to $80 \%$ and more $\mathrm{CH}_{4}$ from rice field during a growing season could be emitted by rice plant-mediated transport. The fully developed aerenchyma of rice plants could be of importance in $\mathrm{CH}_{4}$ emission during rice growing seasons, and responsible for the $\mathrm{CH}_{4}$ emission peak observed at early rice growing season [20]. Therefore, out of total emissions, only small portion of emissions was measured here.

\subsection{Cumulative and Seasonal $\mathrm{CH}_{4}$ Emission from Rice Field}

The cumulative seasonal $\mathrm{CH}_{4}$ emission is presented in Figure 2 where it was found that in CSW condition seasonal trend was similar for all plots while little variation at tillering and matured stage. But the cumulative seasonal $\mathrm{CH}_{4}$ emission in AWD condition was distinguish for different nitrogen applied plot. Methane emission was higher from Heading to flowering, accounting for $38.3 \%$ to $45.6 \%$ of total cumulative emission.

The seasonal $\mathrm{CH}_{4}$ emission was much higher in CSW plots compared with the AWD plots, for all nitrogen treatments (Figure 3). Across the treatments, average total emission under CSW was $850 \mathrm{mg} / \mathrm{m}^{2}$ while it was only $561 \mathrm{mg} / \mathrm{m}^{2}$ under AWD condition. In this study it was found that, AWD emitted 10\%-50\% less methane than CSW under various nitrogen management.

It was found that $\mathrm{CH}_{4}$ flux from rice fields with single and multiple drainages

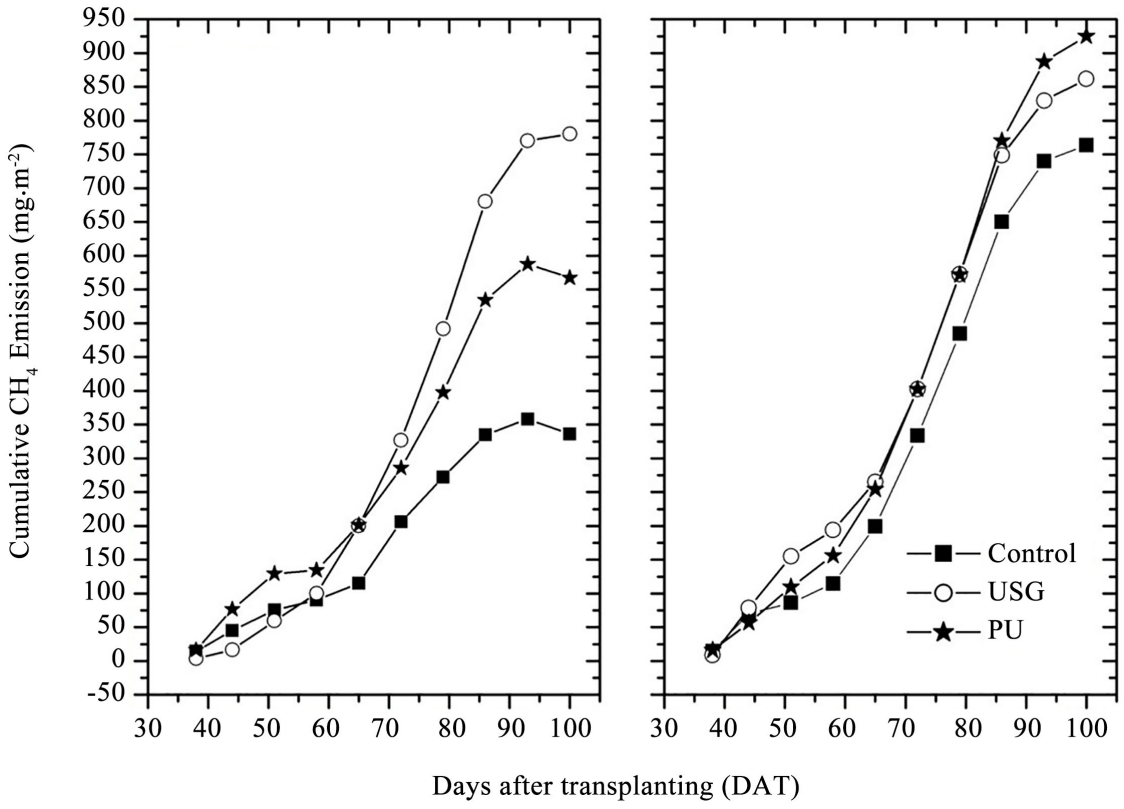

Figure 2. Cumulative methane emissions over sampling period under different nitrogen and water management of Boro rice. (a) AWD; (b) CSW. 


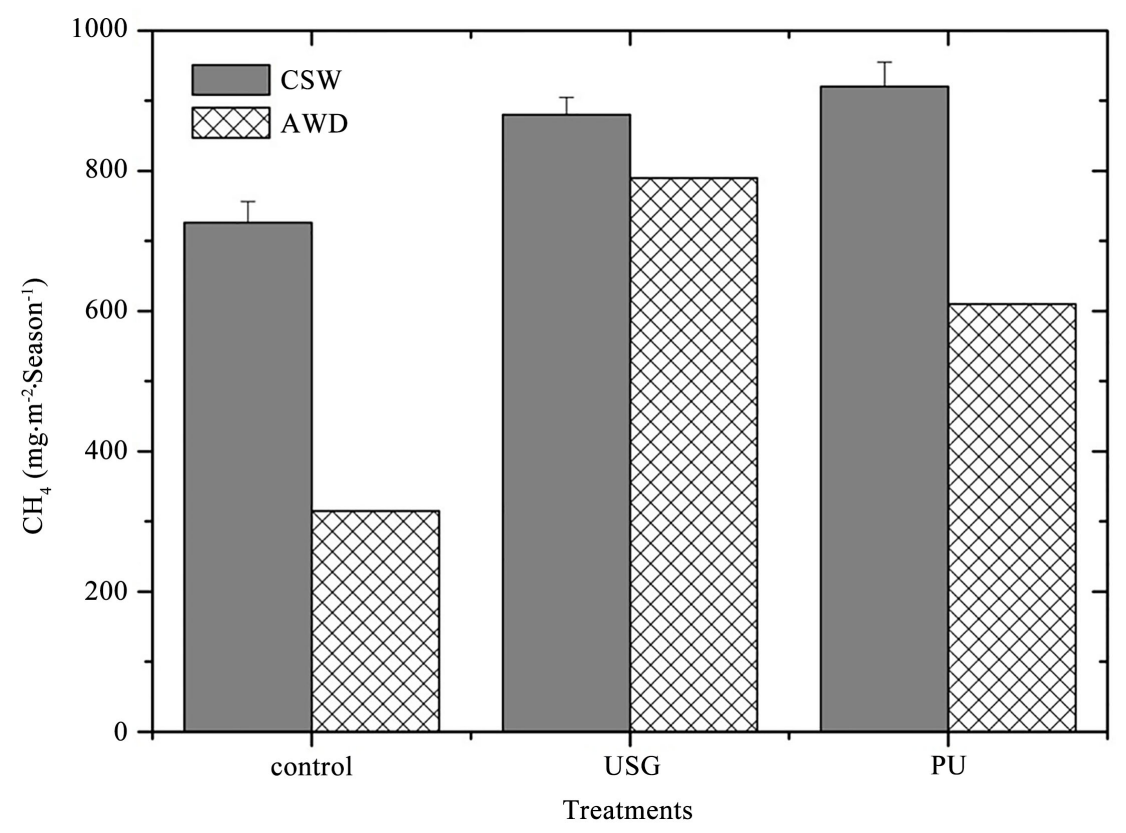

Figure 3. Total methane emission under different nitrogen and water management of Boro rice. Error bar indicate standard error.

was $40 \%$ and $48 \%$ less than that of continuously flooded rice fields, respectively [6]. In another study Sander et al. [21] reported that methane emissions can be reduced by an average of $36.5 \%$ with a single drainage and by $43 \%$ with multiple aerations. Since $\mathrm{CH}_{4}$ emissions increase with plant growth, mitigation options such as drying of the field during later stages (i.e., close to the flowering stage) could result in a greater reduction in $\mathrm{CH}_{4}$ emissions [9]. Continuously flooded conditions yielded two major flushes of methane emission and on an average resulted in relatively higher rate of methane emission. The methane flux was reduced to half when rice fields were irrigated 2 - 3 days after infiltration of flood water into the soil [22].

The average seasonal $\mathrm{CH}_{4}$ emission under nitrogen management was 561, 820, and $750 \mathrm{mg} / \mathrm{m}^{2}$ for control, USG and PU respectively. The variation of $\mathrm{CH}_{4}$ emission across various form of nitrogen application was low but nitrogen induced higher $\mathrm{CH}_{4}$ emission compared with control. A recent meta-analysis conducted on rice paddy fields concluded that smaller amounts of $\mathrm{N}$ fertilizer application stimulated $\mathrm{CH}_{4}$ emission, while larger amounts inhibited it [10] [11]. According to Sass and Fisher [23] maximum emissions correspond to the application of 200 and $300 \mathrm{~kg} \cdot \mathrm{ha}^{-1}$ of urea-N and lower emissions, to 100 and 0 $\mathrm{kg} \cdot \mathrm{ha}^{-1}$ urea-N.

\section{Conclusion}

Rice is currently grown more than hundred countries where they annually produce more than 715 million tons of paddy rice. The majority of rice is grown under irrigated conditions in which the fields are flooded from planting to harv- 
est. Therefore, water saving techniques will help to ensure water security. The field measurements support that $\mathrm{N}$ plays an important role in $\mathrm{CH}_{4}$ production and oxidation in rice fields, but the form of $\mathrm{N}$ is not significant. The overall assessment of results generated out of the experiment suggested that, AWD is better than CSW, because AWD helps to reduce significant amount of methane emission from paddy soil. However, the fertilizer USG is better for CSW and PU is better for AWD condition.

\section{Limitation of the Study}

Gas samples were collected from the exhaust of $\mathrm{N}_{2} \mathrm{O}$ analyzer (Model T320U) because there was no port to collect gas directly from the chambers. Since $\mathrm{N}_{2} \mathrm{O}$ analyzer analyzed gas sample by non-destructive measure, the gas exhausted from the analyzer should be the same concentration as the gas sampled from the chamber. Gas sampling in this study was done without rice plants. AWD treatment was done without replication.

\section{Acknowledgements}

This work was supported by the United States Agency for International Development (USAID) provided support for the research project "Accelerating Agriculture Productivity Improvement-Integrating Greenhouse Gas Emissions Mitigation into the Feed the Future Bangladesh Fertilizer Deep Placement Rice Intensification". We are grateful to Yam Kanta Gaihre, Researcher International Fertilizer Development Center, Dhaka, Bangladesh for his cordial cooperation throughout this study.

\section{Conflicts of Interest}

The authors declare no conflicts of interest regarding the publication of this paper.

\section{References}

[1] BBS (Bangladesh Bureau of Statistics) (2016) The Year Book of Agriculture Statistics. Bangladesh Bureau of Statistics, Ministry of Planning, Government of the People's Republic of Bangladesh, Dhaka, 39.

[2] Solomon, S., Qin, D., Manning, M., Alley, R.B., Berntsen, T., Bindoff, N.L., Chen, Z., Chidthaisong, R., Tignor, M. and Miller, L.H. (Ed.) (2007) The Physical Science Basis. Contribution of Working Group I to the Fourth Assessment Report of the Intergovernmental Panel on Climate Change. Cambridge University Press, Cambridge, United Kingdom/New York, USA, 20-91.

[3] IPCC (Intergovernmental Panel on Climate Change) (2007) The Physical Science Basis. Contribution of Working Group I to the Fourth Assessment Report of the Intergovernmental Panel on Climate Change. Working Paper No. 57, Cambridge University Press, Cambridge, United Kingdom.

[4] Minami, K. and Neue, H. (1994) Rice Paddies as a Methane Source. Climate Change, 27, 13-26. https://doi.org/10.1007/BF01098470 
[5] Denman, K.L., Brasseur, A., Chidthaisong, A., Clais, P.E., Holland, O., Jacob Lohmann, U., Ramachandram, S. and Silva, D.F.L. (2007) Coupling between Changes in the Climate System and Biogcoehemistry. In: Solomon, S., Qin, D., Manning, M., Chen, Z., Marquis, M., Averyt, K.B., Tignor, M. and Miller, M.L., Ed., The Physical Science Basis Contribution of Working Group I to the Fourth Assessment Report of the Intergovernmental Panel on Climate Change, Cambridge University Press, Cambridge, UK/New York, 499-587.

[6] Yan, X., Yagi, K., Akiyama, H. and Akimoto, H. (2005) Statistical Analysis of the Major Variables Controlling Methane Emission from Rice Fields. Global Change Biology, 11, 1131-1141. https://doi.org/10.1111/j.1365-2486.2005.00976.x

[7] Ahmad, S., Lic, D.G., Zhan, M., Wang, J., Pan, S. and Cao, C. (2009) Greenhouse Gas Emission from Direct Seeding Paddy Fields under Different Rice Tillage Systems in Central China. Soil and Tillage Research, 106, 54-61. https://doi.org/10.1016/j.still.2009.09.005

[8] Mishra, S., Rath, A.K., Adhya, T.K., Rao, V.R. and Sethunathan, N. (1997) Effect of Continuous and Alternate Water Regimes on Methane Efflux from Rice under Greenhouse Conditions. Biology and Fertility of Soils, 24, 399-405. https://doi.org/10.1007/s003740050264

[9] Gaihre, Y.K., Padre, T.A., Wassmann, R., Aquino, E., Pangga, G.V. and Sta. Cruz, P.B. (2011) Spatial and Temporal Variations in Methane Fluxes from Irrigated Lowland Rice Fields. The Philippine Agricultural Scientist, 94, 335-342.

[10] Banger, K., Tian. H.Q. and Lu, C.Q. (2012) Do Nitrogen Fertilizers Stimulate or Inhibit Methane Emissions from Rice Fields? Global Change Biology, 18, 3259-3267. https://doi.org/10.1111/j.1365-2486.2012.02762.x

[11] Linquist, B.A., Adviento-Borbe, M.A., Pittelkow, C.M., van Kessel, C. and van Groenigen, K.J. (2012) Fertilizer Management Practices and Greenhouse Gas Emissions from Rice Systems: A Quantitative Review and Analysis. Field Crops Research, 135, 10-21. https://doi.org/10.1016/j.fcr.2012.06.007

[12] IFDC (2007) Mitigating Poverty and Environmental Degradation through Nutrient Management in South Asia. IFDC Report, March 2007. International Fertilizer Development Centre. IPCC (Intergovernmental Panel on Climate Change). The Physical Science Basis. Contribution of Working Group I to the Fourth Assessment Report of the Intergovernmental Panel on Climate Change, Working Paper No. 57, Cambridge University Press, Cambridge, United Kingdom.

[13] Gaihre, Y.K., Singh, U., Islam, S.M.M, Huda, A., Islam, M.R., Satter, M.A., Sanabria, J., Islam, M.R. and Shah, A.L. (2015) Impacts of Urea Deep Placement on Nitrous Oxide and Nitric Oxide Emissions from Rice Fields in Bangladesh. Geoderma, 259-260, 370-379. https://doi.org/10.1016/j.geoderma.2015.06.001

[14] Rahman, F. (2012) Effects of Reduced Rates of Recommended Fertilizer Dose on Cultivation of Bina dhan7. MS Thesis, Department of Soil Science, Bangladesh Agricultural University, 35.

[15] Gaihre, Y.K., Satter, M.A., Singh, U. and Austin, R. (2014) Operating Manual on Automated Continuous Measurement of Greenhouse Gas Emissions. IFDC Technical Bulletin No. T-76, International Fertilizer Development Center, Muscle Shoals, AL 35662, USA, 82.

[16] Van der Hoek, W., Sakthivadivel, R., Renshaw, M., Silver, J.B., Birley, M.H. and Konradsen, F. (2001) Alternate Wet/Dry Irrigation in Rice Cultivation: A Practical Way to Save Water and Control Malaria and Japanese Encephalitis? Research Report 47, International Water Management Institute, Colombo. 
[17] Hossen, S., Islam, N., Alam, R. and Baten, A. (2015) Effects of Different Rates of Compost Application on Methane Emission and Crop Yield in Aman Rice. The Journal of Agriculture and Natural Resources Sciences, 2, 530-536.

[18] Butterbach-Bahl, K., Papen, H. and Rennenberg, H. (1997) Impact of Gas Transport through Rice Cultivars on Methane Emission from Rice Paddy Fields. Plant, Cell \& Environment, 20, 1175-1183. https://doi.org/10.1046/j.1365-3040.1997.d01-142.x

[19] Hussain, S., Peng, S., Fahad, S., Khaliq, A., Huang, J., Cui, K. and Nie, L. (2015) Rice Management Interventions to Mitigate Greenhouse Gas Emissions: A Review. Environmental Science and Pollution Research, 22, 3342-3360. https://doi.org/10.1007/s11356-014-3760-4

[20] Jia, Z.J., Cai, Z.C., Xu, H. and Tsuruta, H. (2002) Effects of Rice Cultivar on Methane Fluxes in a Paddy Soil. Nutrient Cycling in Agroecosystems, 64, 87-94. https://doi.org/10.1023/A:1021102915805

[21] Sander, B.O., Wassmann, R. and Siopongco, J.D.L.C. (2015) Mitigating Greenhouse Gas Emissions from Rice Production through Water-Saving Techniques: Potential, Adoption and Empirical Evidence. In: Hoanh, C., Smakhtin, V. and Johnston, R., Eds., Climate Change and Agricultural Water Management in Developing Countries, CAB International, Oxfordshire, 193-207.

[22] Khosa, M.K., Sidhu, B.S. and Benbi, D.K. (2011) Department of Soils, Punjab Agricultural, Ludhiana University 141004, India. Methane Emission from Rice Fields in Relation to Management of Irrigation Water. Journal of Environmental Biology, 32, 169-172.

[23] Sass, R.L. and Fisher, F.M. (1990) Methane Production and Emission in a Texas Rice Field. Global Biogeochemical Cycles, 4, 47-68. https://doi.org/10.1029/GB004i001p00047 